\title{
THE NARRATIVE AXIS AND NARRATIVE SPACE OF JERIJI KASIH: A TEXT ANALYSIS BASED ON GENUINE LITERATURE
}

\section{Shamsudin Othman}

shamsudean66@gmail.com

\section{MuhammadZarifHassan@Zulkifi}

muhdzarif@putra.upm.edu.my

Department of Language Education and Humanities

Faculty of Education Studies

Universiti Putra Malaysia

\begin{abstract}
The change of literary texts for the subject of Malay Literature in schools brings with it the hope that the text chosen is one of "quality" in order to successfully reach the aims of the National Education Policy. This article is an analysis of the novel Jeriji Kasih (The Confines of Love) which supposedly is written with "an interesting story-telling technique" and is said to be able to impart "knowledge" as well as to shape students into people conscious of goodness, truth and a refined character. The analysis is based on the locallydeveloped framework of Genuine Literature (Persuratan Baru) which aims to examine the extent to which both these claims are true. The main idea in Genuine Literature is the emphasis on "knowledge" as opposed to "narrative". This analysis shows how the text shapes a "narrative axis" and comes together in a "narrative space". The analysis of this text also shows that the "narrative space" has been occupied with the "contents of the narrative" through the manipulation of a number of elements such as character and plot. This analysis reveals that the "knowledge" claimed to be contained in this text diverges from the idea of "knowledge" as put forth by Genuine Literature.
\end{abstract}

Keywords: Genuine Literature, narrative axis, narrative space, knowledge, narrative 


\section{INTRODUCTION}

The novel Jeriji Kasih (The Confines of Love, hereafter referred to as $J K$ ) is a novel by Ramlah Abd. Rashid that has been awarded the consolation prize in the DBP Golden Jubilee Writing Competition. Although this novel only managed to garner the consolation prize, it has been chosen as a set text for students in Malaysian schools taking Malay Literature as a subject. ${ }^{1}$ Clearly, the choice of $J K$ as a text is final, and this choice is a major recognition not only to the novel but also sets a precedent in Malay literature education in the country, as $J K$ is thus considered an authoritative text able to successfully create good individuals, in other words, good students, in line with the National Education Policy. ${ }^{2}$

This recognition given to $J K$ comes based on the support of several quarters, among which is the Report of the Dewan Bahasa dan Pustaka Golden Jubilee Writing Competition (hereafter referred to as the Report). According to the Report, $J K$ deals with themes surrounding family, and is written with "an interesting story-telling technique". ${ }^{3}$ Apart from this, the Report also says that the language of the novel flows smoothly, and is concise and compact, while the dialogue reflects the speech of teenagers. This means that, on the whole, $J K$ is deemed have "an interesting story-telling technique" according to the views of the panel that produced the Report. Moreover, there is also the claim that $J K$ is a novel of quality that contains "knowledge". This has been affirmed by the Director of Education, himself, Tan Sri Dato" Haji Alimuddin bin Haji Mohd Dom, who has stated that:

Novels for the Malay Literature component of the Integrated Secondary School Curriculum (KBSM) have undergone an approval process at the ministerial level by the Education Ministry to ensure the quality of the novels used ... This novel has been carefully chosen in order to fulfil the requirements for the teaching of Malay Literature ... to support the core development of the individual, especially in terms of knowledge, skills and values that are related to intellectual and emotional aspects ... the literary work chosen is able to make the students people conscious of goodness, truth and a refined character... ${ }^{4}$

From the above statement, it can be surmised that the process of choosing $J K$ as a set text was done using a stringent procedure of selection. In any case, the text was not chosen haphazardly, and the quality of its contents was evaluated, and were deemed to contain "knowledge", as well as depicting "goodness", "truth" and "a refined character", as mentioned in the statement 
above. Thus, it can be understood that there are two claims that support the choice of $J K$ as a set text, that is, its "interesting story-telling technique" (refer to the Report) and the "knowledge" it contains which will produce students who are conscious of "goodness", "truth", and "a refined character" (refer to the Foreword). ${ }^{5}$ Two important aspects that must be viewed in detail are the claims concerning "story-telling" and "knowledge" that are the bases on which $J K$ was awarded such high recognition (that of being chosen as a set text for the Malay Literature component in the national education system).

However, the change of set text has invited criticism as there are many who feel that the work chosen seems haphazard and is unsuitable. ${ }^{6}$ According to Fatimah Busu, the panel selecting the text for the Literature Component for the Teaching and Learning of the Malay Language (KOMSAS) and the Malay Language subject, should be more sensitive when it comes to character-building values in a text. In other words, the panel did not emphasize on character-building aspects. She also stated that the chosen text does not depict good moral values that promote character-building. ${ }^{7}$

This issue has been discussed by a literary scholar, Mohd Affandi Hassan (hereafter referred to as Mohd. Affandi). His criticism, although lengthy, needs to be reviewed in order to investigate the actual issue:

The students, as well as their teachers, will in the end be lost in a trivial discussion of alliteration, assonance, personification, response and variation; or launch into passionate bombast when discussing the issues of a shallow and immature text using fantastic rhetoric, to buoy that which, in reality, is empty. This crisis can be seen when a text that lacks quality, or contains negative lessons is selected. As a result of such crisis, the teaching and learning of literature stagnates, it stunts the development of critical thinking and ends the inculcation of good moral values; it becomes dull and uninteresting. ... such teaching of literature will not leave a lasting impression of beauty ... the literature teaching and education will fail in its goals, because the goals are unclear, and the way to achieve them will be chaotic and confusing. Literature is taught as a subject to be passed ... leading to a "revision book culture" of relying on revision books that are shallow, superficial, confusing, misleading and that stunt the mind, written without any academic responsibility ...

From the above, it is clear that there is a deeply-concerning issue in the field of literary studies involving the strength (or rather, the lack of it) of Malay literary texts in general. The emphasis on the selection of text begs the question whether the Malay literary texts chosen, especially the novel $J K$, are suitable reading material for all students in this country. This is 
because a text that does not have "quality" is seen as swerving away from the aims of the national education system, and does not aid in the shaping of an individual as envisioned in the National Education Policy.

The rest of this discussion will analyse the novel $J K$ in an effort to understand aspects of its structural creation and to identify whether such structure was created with a concern for "narrative" and "knowledge". An understanding of "narrative" and "knowledge" as contained in $J K$ is important to evaluate the credibility of $J K$ based on the claims made about it, as shown above. Therefore, the framework of this study is the theory of Mohd. Affandi's Genuine Literature (Persuratan Baru, hereafter shortened to GL). This framework was selected as it is considered to be accurate and will be able to give a fair evaluation of $J K$ as GL's main emphasis is on ilmu (knowledge) as a keutamaan (priority) rather than cerita (narrative) in a literary work. Apart from this, there are other concerns in GL such as paksi naratif (narrative axis) and ruang naratif (narrative space) which underlie a literary work. All these aspects of GL theory are applied in the analysis of a literary text in order to understand whether the focus of the text is "knowledge" or "narrative".

\section{THE ANALYTICAL FRAMEWORK OF GENUINE LITERATURE}

In general, GL is a theory that has two aspects, a philosophical and a practical one. At the philosophical level, GL is held up by three important philosophical elements, that is, Hakikat Insan (the Features of the Being), Hakikat Ilmu dan Amal (the Features of Knowledge and Deeds) and Hakikat dan Fungsi Sastera (the Features and Function of Literature) (Mohd. Affandi Hassan, 1992:15). All three of these philosophical aspects of GL are grounded in a framework of taklif, ${ }^{9}$ that refers to the questions of the bond of human beings to the "Perjanjian Azali" (primordial covenant) of worshipping their Creator, that is, Allah SWT. This is explained by Mohd. Affandi : “...the aim of human creation is none other than to worship Allah" "According to the GL theory, this aim is basic to human nature. It provides the understanding that the refusal of human beings to worship Allah SWT is against human nature.

Moreover, in the "Features and Function of literature", the activity of producing a written work based on the Qalam (pen) must be in line with the true meaning of Qalam from the point of the Qur"an, which in turn teaches human beings the truth with regard to Allah SWT. Mohd. Affandi explains: "Literature is one of the products that emerges out of the use of Qalam (Qalam 
here means the tool used for writing as well as words or language), by itself: ...reflecting truth, that is, the features of knowledge". ${ }^{11}$ This statement means that providing knowledge is one of the main definitions of GL as regards the aims of literature. It is important that the "knowledge" that forms a part of the philosophy behind GL is knowledge that is considered to be truth in accordance with the decree of Allah SWT, i.e. "knowledge" through which human beings are able to recognize their creator. According to GL, each deed that is based on the "true knowledge" must be given priority so that it does not admit anything that could be nonsensical or frivolous. Mohd. Affandi states: "significantly, true knowledge (that does not confuse or lead to doubt) is the basis of all human deeds (actions or efforts): the implication is that all efforts will be in vain and senseless if they are not based on true knowledge". ${ }^{12}$ This proves that "knowledge" is the basis for all deeds and these two features are contained in the "Features of Knowledge and Deeds".

Leading out from the philosophical aspects that have been explained, GL then formulates the second aspect, that is the practical one. As explained above, the practical aspects that are emphasized in this analysis will revolve around two concepts, that is, the narrative axis ${ }^{13}$ and narrative space. ${ }^{14}$ The concept of narrative axis refers to the core issue which is the backbone of the entire narrative, that is the "stance" of the novel with regard to the narrative presented, which highlights the views, attitudes and tendencies of the novel concerning a certain point. Apart from this, the narrative axis also influences the creation of the narrative through a concerted story-telling strategy in order to strengthen the narrative axis. As a basis for the forming of a narrative, the narrative is limited by its beginning and end.

The space that exists between the beginning and end of the narrative is what is meant by the narrative space. Narrative space can be seen as a blank and neutral space that can be filled with certain contents. It must be explained that the narrative space that exists in a work is not considered as a component of "narrative", such as event, conflict, character, action, tension, and so forth (Mohd. Zariat Abdul Rani \& Ungku Maimunah Mohd Tahir, 2005:379). Based on its neutral characteristic, the narrative space can be filled with contents in the form of "narrative" or "discourse". "Narrative content" refers to event, conflict, character and characterization, plot and so forth that are combined to trigger, develop and maintain the storyline of a narrative (Mohd. Zariat Abdul Rani \& Ungku Maimunah Mohd Tahir, 2005: 378). Whereas "discourse content" refers to a salient idea presented in a serious way. The "idea" of the author does not refer to the inspiration for 
the narrative, instead, it refers to the work's underlying intellectual idea or reason, presented in an intellectual manner, with explanations and supporting arguments that are solid and well-arranged (Mohd. Zariat Abdul Rani, 2010: 400). Within this idea, the process of forming a discourse involves argument and reasoning, explanatory debate, opposition, explanation, analysis, explication, commentary and so on (Ungku Maimunah Mohd. Tahir, 2007: 61). With reference to "discourse", it must be said that the "narrative" is a vessel for argumentation or "knowledge", not that "knowledge" gives meaning to the "narrative"; therefore, "narrative" is always considered secondary to "knowledge" (Ungku Maimunah Mohd. Tahir, 2009:88). It can be understood from the above that a novel which emphasizes "knowledge" may fill its narrative space with "discourse content", while the "narrative" is used to contain the idea that is to be presented. The difference is obvious in novels that emphasize "narrative", as the "narrative content" dominates their narrative space.

This analysis will apply the ideas discussed above to evaluate the claims supporting the selection of $J K$. As the work is said to contain both "narrative" ("story-telling") and "knowledge", the analysis is expected to provide answers as regards the narrative structure of $J K$, especially concerning the priority of the novel, whether this priority is "knowledge" or "narrative". Apart from this, through this analysis, the question of whether $J K$ deserves the recognition it has received as an authoritative text in the national education system should be answered.

\section{ANALYSIS OF THE NOVEL JERIJI KASIH ${ }^{15}$ BASED ON GENUINE LITERATURE}

As mentioned earlier, this analysis will focus on two important concepts, the narrative axis and the narrative space in explaining the narrative structure of $J K$. In connection with this, it is important to note that the process of creating a narrative begins with the establishing of a narrative axis which will be the backbone of the entire narrative structure of the novel.

In order to identify the narrative axis that is the backbone to $J K$, one must first look at the statement made in the Report, that is that "the novel Jeriji Kasih deals with the theme of family". This claim in the Report is similar to the wording in the blurb of the novel: 
The peaceful life of Anuariza, a young village woman who has a disability but who is also resilient, is disrupted by the arrival of the family of Syed Mustafa... Anuariza finds herself becoming the staff on which this family, who is starved of love, leans. She is able to handle the situation, although she is not able to deal with Syed Mustafa's daughter ...

From the above, the claim that $J K$ deals with " the theme of family" can be seen to be related to Syed Mustafa's family. However, when viewed closely, it can be seen that the statement "disrupted by the arrival of the family of Syed Mustafa", conveys the first impression that there is something unsettling that will create a conflict, as the arrival of the Mustafa family "disrupts" Anuariza's "peaceful life" (quoted from blurb). What needs to be given attention is the question of conflict, which is also related to the statement that "she is able to handle the situation, although she is not able to deal with Syed Mustafa's daughter", which leads one to understand that the problem is the behaviour of Syed Mustafa's daughter. The problem is then a "behavioural" one, which calls to mind a personality disorder. It is important to note that behavioural problems are usually related to character, personality, characteristics, values, and attitudes that lean towards the negative in the novel $J K$. This is supported by the word "handle" in the blurb, which suggests the successful solving of the problem that arises out of the personality disorder, and which needs to be dealt with. This analysis, then, suggests that the author has chosen "behavioural problems" or a negative personality as the narrative axis for the novel. Apart from this, the author's choice to write about personality disorder can be seen from the title of the novel, Jeriji Kasih (literally, "the bars or love"). Jeriji Kasih implies "confined loved", and suggests that there is a "lack of love". This is supported by the wording of the blurb that states that one of the conflicts in the novel is due to being "starved of love".

It must be explained that the issue of being "starved of love" (refer to the blurb) is the cause, which in the end has as its effect the "behavioural problem". The personality disorder is thus what forms the narrative axis of the novel. Focusing the narrative axis on this issue, enables the filling of the narrative space by focusing on the issues of values, personality and attitude, which clearly leans to the negative, and is manipulated through such narrative components as event, character and characterization, plot and so forth. Also, leaning on such a narrative axis gives the author the opportunity to imbue the protagonist, Syed Fariz, with negative morals. This signifies 
that the beginning of the novel leans towards the negative, which will gain further room in the narrative space.

Further, based on such a narrative axis, the narrative space of $J K$ has been shaped from the beginning to the end of the narrative. In the beginning, $J K$ is marked through the move of Syarifah Farisya and Syed Fariz, Syed Mustafa's children, to their new home in the kampung to live with their grandmother, Nek Siah. The move is because Syed Mustafa is busy with work, and also because of the death of his wife, Jumaimah. Because of this, Syed Mustafa leaves the task or raising his children to his mother, Nek Siah in the kampung. However, it must be mentioned that the removal of Syarifah Farisya and Syed Fariz to the kampung is not merely because of the problems Syed Mustafa is facing himself, but is motivated also by the negative personality of Syed Fariz, who, for example, was suspended from school for misuse of cough syrup and who even "pushed" cough syrup before being sent to the kampung. As mentioned above, the narrative axis of the novel is personality disorder, which is the cause behind the presence of Syed Fariz and Syarifah Farisya in the kampung. As explained, the narrative axis from the beginning of the "narrative" of $J K$ has already been established and enables the novel's narrative space to be filled with issues concerning personality disorder.

The novel combines a number of narrative tools to fill its narrative space. The most obvious is the manipulation of character and characterization, especially where Syed Fariz is concerned. It must be highlighted that the manipulation of character and characterization is not just confined to the character of Syed Fariz alone but can also be seen in other characters such as Anuariza, Syed Mustafa and Syarifah Farisya. The analysis shows that the character of the protagonist is manipulated through the insertion of a complex problem of personality disorder. The analysis reveals that the character of Syed Fariz is one who is closely linked with the narrative axis of $J K$ because the character is depicted as a youth who has characteristics and a personality that is full of negative traits. Among the characteristics and values that are given to the character are that he is uninterested in his studies, stubborn, ill-mannered and rebellious, plays truant; also that he is a trend-follower, and a gangster and bully who smokes, sniffs glue, steals and spends his ill-gotten gains on luxuries, is involved in misuse of cough syrup, and molests a girl named Ruhaiza.

It must be understood that the novelist has drawn this character as one who is full of negative traits, and this leads to the understanding that the 
novel requires a large narrative space. In order to fulfil the requirements to widen space between the beginning and the end, and increase the number of pages in the novel, it cannot be denied that the novel has chosen a "narrative content" that is full of negativity.

To fulfil this requirement, the manipulation of the characters weakens some of the characters such as Anuariza, Syed Mustafa and Syarifah Farisya in order to move the plot forward. By weakening or downplaying these characters, the negative aspects of the protagonist are highlighted. In $J K$, Anuariza has been asked by Syed Mustafa to tutor Syed Fariz, while at the same time guiding Syed Fariz, who is ill-mannered and rebellious, to be a better person. However, the analysis reveals that the weakening of Anuariza's character is clearly seen when, during the protagonist's period of bad behaviour, she is unable to restrain, what more to change Syed Fariz. Although the character of Anuariza is created as one who is "resilient" (wording of the blurb), "of high character, good personality, and intelligent" (wording in the Report), overcome the negative characteristics of the protagonist. It can be surmised that the character of Anuariza, who is characterized as "resilient" and "of high character, good personality, and intelligent", is weakened on purpose, so that the character of the protagonist with his personality disorder is highlighted and allowed to dominate the narrative space of $J K$. It may not be an exaggeration to say that the presence of the character of Anuariza is merely to accompany the protagonist, not to function as a character capable of restraining or changing the protagonist. Therefore, the indication in the blurb that Anuariza is able to handle the protagonist's behavioural problems is inaccurate.

The same is true of the character of Syarifah Farisya, who is incapable of advising the protagonist to change, in fact, she even has to lie to Nek Siah to hide the protagonist's actions from being known by the rest of the family. Clearly, it can be inferred Syarifah Farisya's lying is a kind of acquiescence to the immoral activities of the protagonist, which further strengthens the narrative axis of $J K$.

This strategy of downplaying or weaning of characters can also be seen in the depiction of Syed Mustafa. By depicting the father as "materialistic" and "irresponsible", working far away in the city, it shows the lack of supervision and control of the character of the father towards the protagonist. This lack is what enables the novel to deal at length with protagonist's negative characteristics as the wider "narrative content" of the novel. At this point, it is proven that "narrative" is the focus of the novel with regard to its "narrative space". 
Close observation reveals that "narrative" is the main issue for the author of $J K$. This can be seen from the "narrative content" which fills the "narrative space" of $J K$ with depictions of delinquency. Analysis reveals that the erotic (the protagonist's molestation of Ruhaiza) is the climax of the protagonist's negative aspects in the fictitious world of $J K$. The depiction of this erotic episode is meant to show the "animalistic" side of the protagonist as he takes advantage of Ruhaiza. This can clearly be seen in the following excerpt :

\section{Sehelai demi sehelai pakaian Ruhaiza ditanggalkan mereka sebelum diserahkan kepada Syed Fariz... Syed Fariz bertindak seakan-akan binatang buas menggomol sesuka hatinya dengan ditonton rakan-rakannya yang bertepuk sorak kegirangan seperti penyabungan ayam jantan.}

(Ruhaiza's clothes were removed one by one and handed to Syed Fariz... Syed Fariz was like a wild animal groping to his his heart's content, watched by his friends who cheered and clapped as if watching a cock-fight.)

When looked at closely, the above depiction of Ruhaiza's molestation is likened to "a cock-fight" and becomes something of a celebration as an act of revenge against Ruhaiza who had reported the protagonist and his friends to the discipline teacher. Through the above excerpt, it can be surmised that the protagonist is someone who has a delinquent, cruel and animal nature.

This idea of a cruel, delinquent and animal nature further strengthens the narrative axis of $J K$. It is important here to mention that the analysis reveals that the erotic episode moves the plot forward and widens the narrative space. Filling the narrative space with an erotic episode merely provides more emphasis on "narrative", and not "knowledge".

Further, in filling the "narrative space" of $J K$, the novelist manipulates an important aspect of narrative, that is, plot. To simplify the discussion, the plot is divided into two subplots, that is, the plot concerning Syed Fariz (subplot I) the plot concerning Syarifah Farisya (subplot II). This division is not to show an actual division into subplots but to show the continuity of the plots in $J K$. Analysis reveals that there is a parallel that runs through subplot I and subplot II, connecting the two to create a solid narrative.

A has been explained earlier, the arrival of Syed Fariz in the kampung provides the novel with a character that is negative. What is interesting to observe is that with these negative characteristics, the plot concerning Syed Fariz (subplot I) is allowed to develop widely. The issues of personality disorder that are connected to the protagonist are arranged in a certain order 
and develop in stages. The development of the plot involving Syed Fariz (subplot I) traces his negative characteristics and arranges them in a certain order, creating a continuity from one chapter to another, and dominating the "narrative space" of $J K$. It can be seen that the order in which the negative aspects are arranged begin with "not being interested in studies" to the "molestation of Ruhaiza", and take up a large space within the novel. The depiction of Syed Fariz's gradual worsening behaviour and morals takes up almost 24 of the novel's 30 chapters. Clearly, the novel purposely fills its narrative space with "narrative content" that is immoral, through the depiction of its protagonist.

The plot revolving around Syarifah Farisya (subplot II) is about Syarifah Farisya not agreeing that her father, Syed Mustafa, marry Solehah, Anuariza's mother, because Syarifah Farisya loves Anuariza. This conflict between Syarifah Farisya and Syed Mustafa, causes Syarifah Farisya to run away from home in protest. It must also be pointed out that Syarifah Farisya's story (subplot II) shows that the narrative space of $J K$ is filled with "narrative content" that is still concerned with behavioural problems as shown by Syarifah Farisya. This shift in depiction of negative characteristics from the protagonist to Syarifah Farisya shows that there is an effort in the novel to uphold the narrative axis of the novel. In order to move the plot forward, the novelist has also employed an important element in narrative structure, that is, the law of cause and effect. In other words, there is a link between the plot revolving around Syed Fariz (subplot I) and the one revolving around Syarifah Farisya (subplot II) which displays a strengthening of the narrative axis that allows the plot involving Syarifah Farisya (subplot II) to be developed.

Analysis shows that the plot revolving around Syarifah Farisya (subplot II) is established when Syed Mustafa decides to marry Solehah after the plot involving Syed Fariz (subplot I) is established. This situation is strengthened when Syed Mustafa makes the decision to give up his job in the city and return to the kampung after hearing that Syed Fariz has been arrested as a result of molesting Ruhaiza. Syed Mustafa's decision to return prompts him to consider marrying Solehah. Clearly, the plot centring on Syarifah Farisya (subplot II) could not have been established or developed without the existence of the plot centring on Syed Fariz (subplot I) due to the absence of cause and effect in such case. This means that the plot centring on Syed Fariz (subplot I) is the cause that brings about the plot revolving around Syarifah Farisya (subplot II). 
This explanation serves to show that the narrative axis is strengthened by the novelist through the filling of the "narrative space" from the beginning to the end of the novel. It is clear that the main concern in $J K$ is a negative "narrative content" to the extent that no "discourse content" can really be discerned in the novel.

\section{CONCLUSION}

An analysis of the narrative axis and narrative space of $J K$ shows that the narrative axis is based on the issue of behavioural problems or personality disorder, and this is what influences the narrative. The issue of behavioural problems or personality disorder which forms the narrative axis is then forged into a narrative that occupies the "narrative space" of $J K$ by the author. Therefore, the novel's narrative space is taken up completely by pure "narrative" that concerns itself with behavioural problems or personality disorder presented through narrative components such as character, causeeffect and plot. In connection with this, it is obvious that the novel is full of elements of juvenile delinquency and shows that the novel is ultimately more concerned with "narrative" than "knowledge". Through this discussion, the claim that $J K$ contains or presents "knowledge" which can lead students to think about "goodness", "truth" and "a refined character" can clearly be refuted.

\section{NOTES}

1 Refer to the circular issued by the Office of the Director of the Malaysian Department of Education dated 25 November 2009, reference number KP(BPSH-SPDK) 201/005/02/ (27) concerning the replacement of the literary text for the Malay Literature elective subject for Forms 4 and 5 beginning 2010.

2 For further clarificaiton on the National Education Policy, refer to the Ministry of Education Malaysia, Pukal Latihan Kurikulum Bersepadu Sekolah Menengah Falsafah Pendidikan Negara (The National Education Policy Integrated Training Curriculum Volume for secondary Schools), Kuala Lumpur, Dewan Bahasa dan Pustaka, 1992, pp. 8-15.

3 According to the Report of the Dewan Bahasa dan Pustaka (DBP) Golden Jubilee Writing Competition, the novel Jeriji Kasih carries themes concerning family; a youth in her early 20s named Anuariza (who has a birth defect on her left hand) is waiting for her STPM results and has ambitions to enter university. Anuariza is a wise young woman of good character, intelligent, and diligent in helping her adoptive mother. The 
storytellinng is interesting as it is written in a language that is concise, compact and coherent, with dialogue reflecting the speech of young people. For further reference, see Zalila Sharif, Laporan Sayembara Mengarang Sempena Sambutan jubli Emas DBP (Report of the DBP Golden Jubilee Writing Competition), Dewan Sastera, March 2007, pp. 28-29.

4 Refer to the Foreword of the Director of the Malaysian Education Department in Ramlah Abd. Rashid, Jeriji Kasih, Ministry of Education Malaysia, Dewan Bahasa dan Pustaka, 2009.

5 There are also personal views concerning $J K$ as being a good work illustrating the values as promoted by the Malaysian Ministry of Education. Please refer to http://www. bharian.com.my/bharian/articles/KemeluttekssasteraKOMSAS/Article. Retrieved on 27 April 2011.

6 Concerning the selection of literary texts for use in the national education system, as was once mentioned by the National Literature Laureate Dato' Anwar Ridhwan himself in a speech: "the selection of several other works or texts seems haphazard, to the extent that the works of several younger writers, some of them little known, were also included. This shows a shallow understanding by the people who make the selection concerning the actual "role" of literary texts". Refer to Anwar Ridhwan, "Perjuangan Penulis Muda : Arah dan Cabaran", Perhimpunan Penulis Muda Nasional 2009, organized by Persatuan Penulis Nasional (PENA), Dewan Bahasa dan Pustaka, in conjunction with Majlis Bandaran Melaka Bersejarah, Akademi Seni Budaya dan Warisan Kebangsaan, and Dewan Bahasa dan Pustaka Wilayah Selatan at the Puteri Resort, Melaka, on 22-24 May 2009. Several articles deal with the issue of text selection including "Teks Sastera Kena Pikat Penulis Muda", Berita Harian, 29 January2008, “Teks Sekolah Tak Senarai Karya Sasterawan Negara”, Berita Harian, 12 January 2008, "Karya Bermutu Wajar Jadi Teks Sastera", Berita Harian, 15 January \& "Cadang Karya Sasterawan Negara Jadi Teks Sekolah", Berita Harian, 17 January 2008.

Also refer to the article "Kemelut KOMSAS, Sastera Elektif oleh Salbiah Ani” http:// dbp.gov.my/lamandbp/main.php?Content=articles\&ArticleID=1435.

7 Dr Fatimah Busu's comments on the matter can be viewed at http://www.bharian.com. my/bharian/articles/KemeluttekssasteraKOMSAS/Article. Retrieved on 27 April 2011.

8 Quoted from Mohd. Affandi Hassan, 1991. Pendidikan Estetika daripada Pendekatan Tauhid. Dewan Bahasa dan Pustaka, Kuala Lumpur, pp. 4-5. Subsequently referred to as Pendidikan Estetika.

9 Mohd. Affandi has employed the definition of taklif as used by Syah Waliyullah alDihlawi (r.h.) as "the weight of law on humans" or the bond of responsibility of carrying out the decrees of Allah SWT. According to Syah Wali Allah, human beings are bonded to taklif and this is characterized in three ways, which are justice, knowledge and effort. Refer to Syah Waliyullah al-Dihlawi, Hujjah Allah al-Balighah, Argumen puncak Allah: Kearifan dan Dimensi Batin Syariat. Jakarta: Pt. Serambi Ilmu Semesta, p. 15.

10 Mohd. Affandi Hassan uses as a starting point the view of Prof. Dr. Syed Muhammad Naquib Al-Attas wo explains that human beings are indebted to Allah SWT, with whom they have a primordial covenant as mentioned in surah al-Araf, verse 174. Prof. Dr. Syed Muhammad Naquib Al-Attas also explains the concept of fitrah (human nature) in detail. Refer to Syed Muhammad Naquib Al-Attas, Islam and Secularism, International 
of Islamic Thought and Civilazation (ISTAC), Kuala Lumpur, 1993, pp. 51-95.

11 Pendidikan Estetika Tauhid, op. cit. p. 15

12 Pendidikan Estetika Tauhid, op. cit. p. 23.

13 The term paksi naratif (narrative axis) was first used by Mohd Affandi in his article "Era "Picisan dalam Sastera Melayu: Shahnon, Azizi, Rohman Shaary", Dewan Sastera, July, 2002, pp. 44-47. However, his meaning of "narrative axis" is explained in several earlier writings especially when discussing evil as the "main theme" and "aestheic expression" (both Mohd. Affandi's terms) in modern Malay literature. For further understanding , refer to Mohd. Zariat Abdul Rani, "Islam and Narrative Axis: A critical Analysis of Salina by A. Samad Said", paper presented at the Malaysian International Conference on Languages, Literatures and Cultures (MICOLLAC) 2005, organized by the Department of English, Faculty of Modern Languages, Literatures and Communication, Universiti Putera Malaysia, at Holiday Villa, Subang Jaya, on 23-25 April 2005 \& Mohd. Zariat Abdul Rani, "Islamic Polygamy and Narrative Employment in Tok Guru and Ummi \& Abang Syeikhul by Shahnon Ahmad", a paper presented at the 22nd Conference of Association of South East Asian Studies (ASEASUK) 2005, at the University of Exeter, Exeter, on 29 April-1 May 2005.

14 The term ruang naratif (narrative space) was first used by Profesor Ungku Maimunah while supervising the doctoral thesis of Prof. Madya Dr. Mohd. Zariat Abd. Rani titled "Seksualiti dalam Novel-novel Melayu : Satu Analisis Teks Berdasarkan Persuratan Baru” (2004), Institut Alam dan Tamadun Melayu (ATMA), Universiti Kebangsaan Malaysia. For further reference concerning "narrative space", refer to Mohd. Zariat Abdul Rani \& Ungku Maimunah Mohd. Tahir, "The Employment of Narrative Space in Hikayat Faridah Hanom by Syed Syeikh Al-Hadi and Pujangga Melayu by Mohd Affandi Hassan : A Comparative Analysis", paper presented at the 13th Colloqium of The Malaysia Society of Australia, "Globalisation, Islam and Identity in Malaysia and Singapore”, Faculty of Asian Studies, Australian National University (ANU), Canberra, Australia, 26-27 November 2004. This article is also available in Malay: "Persuratan Baru dan Penggemblengan Ruang Naratif: Satu Kajian Perbandingan Antara Hikayat Faridah Hanom oleh Syed Syeikh Al-Hadi dengan Pujangga Melayu oleh Mohd. Affandi Hassan", in Hajijah Alias \& Muhammad Ikhram Afdhly Hussin (Chair) Seminar Teori dan Kritikan Sastera Melayu Serantau, Dewan Bahasa dan Pustaka, Kuala Lumpur, 2005, pp. 374-422.

15 The text referred to in this discussion is Ramlah Abd. Rashid, Jeriji Kasih, Kementerian Pelajaran Malaysia \& Dewan Bahasa dan Pustaka, Kuala Lumpur, 2009.

\section{REFERENCES}

Mohd. Affandi Hassan, 1992. Pendidikan Estetika daripada Pendekatan Tauhid. Kuala Lumpur: Dewan Bahasa dan Pustaka.

Mohd. Affandi Hassan, Mohd. Zariat Adbul Rani \& Ungku Maimunah Mohd. Tahir, 2008. Gagasan Genuine Literature : Pengenalan dan Penerapan. Bangi. Institut Alam dan Tamadun Melayu (ATMA), Universiti Kebangsaan Malaysia.

Mohd. Zariat Abdul Rani, 2010. "Ilmu dan Penjanaan Ilmu Dalam Novel Melati Kota 
Bharu Karya A. Kadir Adabi: Satu Bacaan Intelektual”, pp. 383-444 in Ungku Maimunah Mohd. Tahir (ed.) 2010. Kedudukan Ilmu dalam Kesusasteraan: Teori dan Praktis. Bangi: Institut Alam dan Tamadun Melayu (ATMA), Universiti Kebangsaan Malaysia.

Mohd. Zariat Abdul Rani \& Ungku Maimunah Mohd. Tahir, 2005. "Genuine Literature dan Penggemblengan Ruang Naratif: Satu Kajian Perbandingan Antara Hikayat Faridah Hanom oleh Syed Syeikh Al-Hadi dengan Pujangga Melayu oleh Mohd. Affandi Hassan". pp. 374-422. Seminar Teori dan Kritikan Sastera Melayu Serantau, 2005. Kuala Lumpur: Dewan Bahasa dan Pustaka. Ramlah Abd. Rashid, 2009. Jeriji Kasih. Kuala Lumpur: Kementerian Pelajaran Malaysia \& Dewan Bahasa dan Pustaka.

Ungku Maimunah Mohd. Tahir, 2007. Kritikan Sastera Melayu: Antara Cerita dengan Ilmu. Bangi: Penerbit Universiti Kebangsaan Malaysia.

Ungku Maimunah Mohd. Tahir, 2009. Dinamika Pemikiran Sastera Melayu. Kuala Lumpur: Dewan Bahasa dan Pustaka.

(Translated by Tanja Jonid) 